http://dx.doi.org/10.11646/zoosymposia.15.1.10

http://zoobank.org/urn:lsid:zoobank.org:pub:AC7E944D-52F3-41DE-8B8F-9320FFDFBCA2

\title{
Crinoids lived around the Cretaceous seeps: the second example from cold-seep deposit in the Yezo Group in Hokkaido, Japan
}

\author{
MOE KATO ${ }^{1}$ \\ ${ }^{1}$ School of Natural System, College of Science and Engineering, Kanazawa University, Kakuma, Kanazawa 920-1192, Japan, E-mail: \\ katomoe@staff.kanazawa-u.ac.jp
}

\begin{abstract}
Cold seep deposits are characterized by authigenic carbonates with very low $\delta^{13} \mathrm{C}$ signatures and specific fossils of chemosynthetic community members. These members are mainly composed of mollusks, whereas only a few occurrences of fossil echinoderms from cold seep deposits have been reported. The information of paleoecology of fossil echinoderms in or near cold seep environments is also sporadic. Allochthonous columnal fossils of an Isocrinina crinoid species were found in a boulder of Cretaceous cold seep carbonate from the Yezo Group in northern Hokkaido. The stable carbon isotope of the fossil crinoid specimens showed very low values, approximately $-30 \%$ (VPDB) or much lower value. The low $\delta^{13} \mathrm{C}$ signatures of the seep crinoids and their mode of occurrences suggest that the fossil crinoids lived near the seep environment, and they assimilated low $\delta^{13} \mathrm{C}$ organic particles shifted from there.
\end{abstract}

Key words: crinoid, chemosynthetic community, cold seep, stable carbon isotope, paleoecology

\section{INTRODUCTION}

A cold seep (or a methane seep) is a place where reduced compounds, mainly methane and hydrogen sulfide, emerge from the seafloor, and is one of the peculiar environments inhabited by a chemosynthetic community (Paull et al. 1984; Sibuet \& Olu 1998). Authigenic carbonate is often precipitated through chemical reactions of calcium ion in seawater with carbonate ion produced through anaerobic oxidation of methane in cold seep environment. The precipitated carbonate sometimes can form distinct topographic features such as mounds and platforms on the sea floor (Levin, 2005). Methane from cold seeps and associated carbonate rocks exhibit extremely low stable carbon isotope ratio $\left(\delta^{13} \mathrm{C}\right)$, lower than about $-30 \%$, because methane from cold seeps usually originates from methanogens or thermogenic decomposition of organic matters (Peckmann \& Thiel 2004). Ancient cold seeps have also been recorded from all around the world (Campbell et al. 2002; Campbell 2006).

The seep carbonates are characterized by "brecciated" carbonate rocks with low $\delta^{13} \mathrm{C}$ values, and fossil assemblages such as vestimentiferan tubeworms and some characteristic molluscan species. Although echinoderms were not regarded as a member of chemosynthetic community, Kato et al. (2017) showed an example that the morphologically peculiar stalked crinoid, Lakotacrinus brezinai, from Upper Cretaceous Pierre Shale Formation (Campanian) of South Dakota, USA used carbon derived from methane for their skeletal formation. Considering that the crinoid stalks are endoskeleton, Lakotacrinus brezinai also used carbon derived from the methane for their soft body. Thus, they interpreted crinoids can be a member of chemosynthetic community.

Fossil crinoids, which can be assigned to the suborder Isocrinina, have been found in the Upper Cretaceous cold seep deposits of the Yezo Group, Hokkaido, Japan. This is the second occurrence of fossil crinoids from cold seep deposits, following the previous occurrence (Lakotacrinus brezinai) from the Pierre Shale Formation of the U.S. Western Interior (Landman et al. 2012; Hunter et al. 2016; Kato et al. 2017). 
To evaluate if the crinoids from the Campanian seeps of the Yezo Group were a member of a chemosynthetic community, this paper conducted to describe the fossil crinoids, and analyze stable carbon and oxygen isotopes.

\section{GEOLOGICAL SETTING AND MATERIALS}

The Cretaceous Yezo Group is widely distributed in N-S direction in the central part of Hokkaido, Japan. The equivalent deposits extend toward north in Sakhalin and Kamchatka (Russia). The group was deposited along a westward subduction margin in the north-eastern Asian continent during the Cretaceous (Takashima et al. 2004). This group consists approximately of 10,000-m-thick forearc sedimentary sequence of sandstones and mudstones with subordinate conglomerates. The geological age of this group ranges from early Aptian to early Maastrichtian (Takashima et al. 2004). The Yezo Group is unconformably capped by the upper Eocene, non-marine and shallow-marine sediments of the Ishikari and Poronai groups, or by younger Neogene deposits (Takashima et al. 2004).

The crinoids used in this study were collected from Gakkonosawa locality (Fig. 1). The age of the deposit of this locality is uncertain because the seep carbonates are distributed as boulders along the Gakkonosawa Creek. Based on the comparison with other seep-carbonate localities in the Nakagawa area (Hikida et al. 2003; Jenkins et al. 2007), of which the ages are concentrated to the Campanian of the Omagari Formation, the boulders from Gakkonosawa are also presumed to be of Campanian (Kaim et al. 2008). The Gakkonosawa seep carbonates contain abundant worm tubes, provannid gastropods (Kaim et al. 2008) and columnals of the crinoid (Fig. 2).

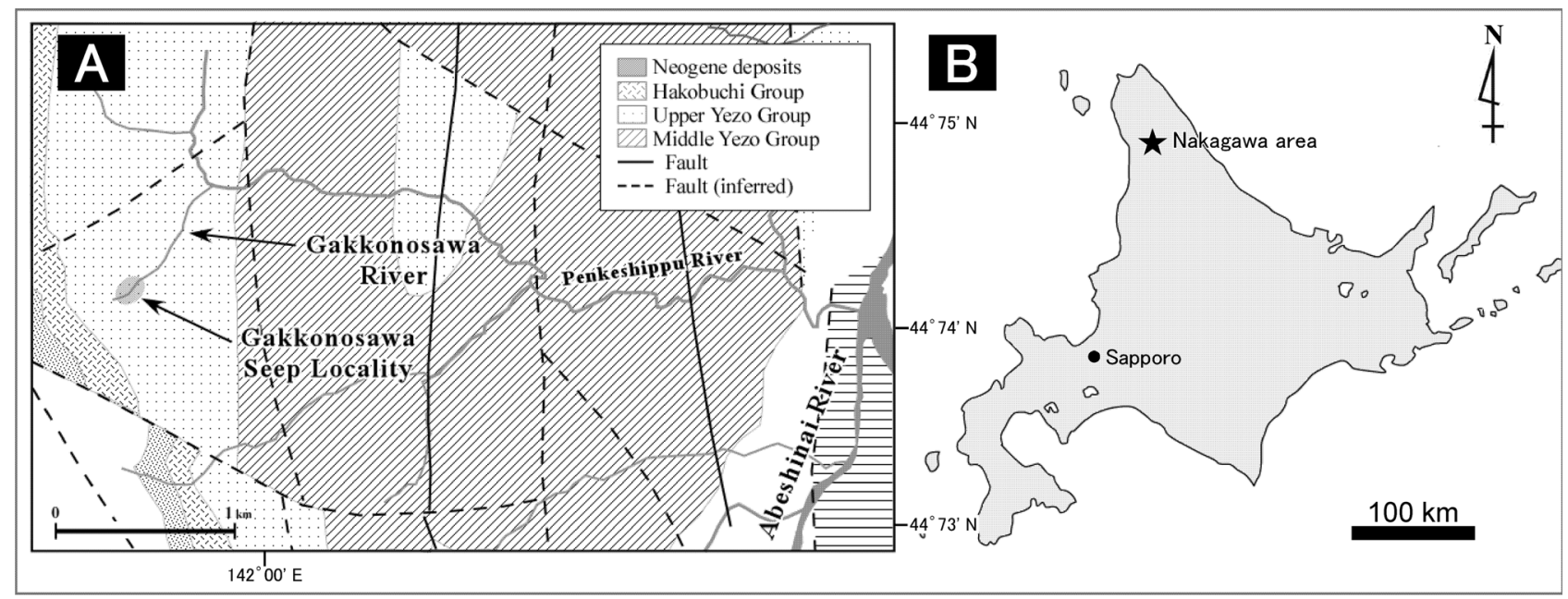

FIGURE 1. A: geological map of Gakkonosawa River area and the locality of cold seep carbonates, modified from Takahashi et al. (2004, Fig. 1), and B: map of northern Hokkaido, Japan. Star is Nakagawa area which including Gakkonosawa locality.

Almost all the crinoid specimens occurred from the cold seep carbonate boulders are associated with tube worms. Ten or more columnals of the crinoid were collected; they are disarticulated, consisting of a few to several articulated pluricolumnals. Because of their occurrence condition, it is thought that they were transported from somewhere to the cold seep environment after their death and trapped in seep carbonates. Well-preserved specimens of this crinoid were used for microscopic observation and stable isotope analysis.

For comparison, two fossil crinoid samples from another non-seep locality between the Kosei bridge and the Miyashita bridge in Tappu, Obira city in the western part of Hokkaido were used for stable isotope analysis; one is presumably derived from the Haborogawa Formation (Coniacian) (Takahashi et al. 2003), and the other is contained in nodule. The non-seep crinoid specimens were collected and provided by K. Tanoue. All these crinoid specimens are registered in the University Museum, Nagoya University under the registration numbers NUM Fa 240-241. 

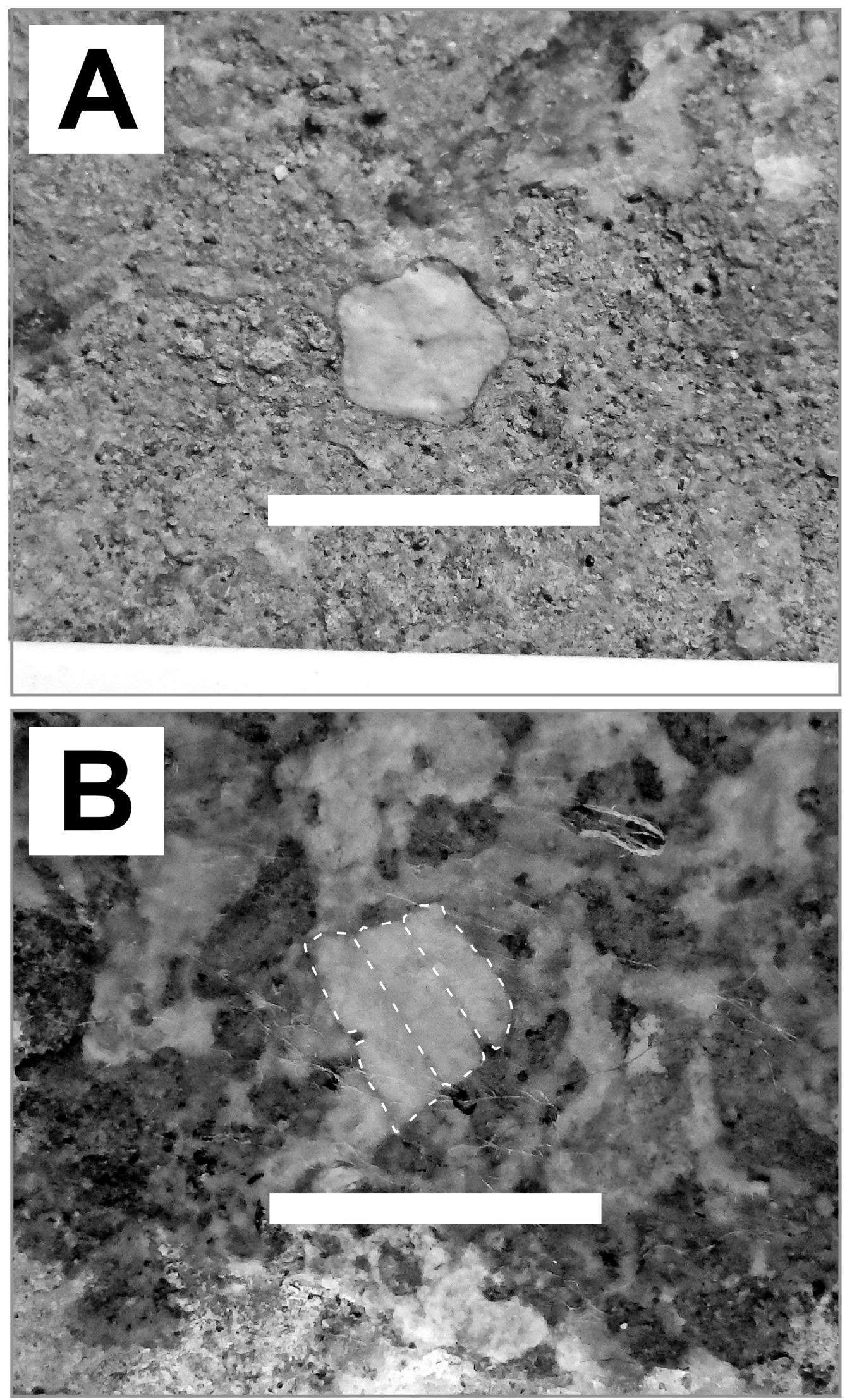

FIGURE 2. Fossil crinoids from the cold seep carbonate boulders in the Yezo Group, Hokkaido. A; a pentalobate columnal. B; a cross section of three columnals attached. All scale bars show $10 \mathrm{~mm}$. 


\section{METHODS}

\section{Microscopic analysis}

The binocular microscope (SZX7, Olympus, Japan) was used for observation of fossil crinoid morphologies. The carbonate rock samples including crinoids were cut into standard thin sections and polished for a microscopic observation. A polarizing microscope (Eclipse 50i POL, Nikon, Japan) in the Laboratory of Petrology and Geobiology, the Department of Earth and Planetary Science, Nagoya University was used for the analysis of fossil microstructures.

\section{Stable isotope analysis}

The $\delta^{13} \mathrm{C}$ and $\delta^{18} \mathrm{O}$ of the fossil crinoid skeletons and the carbonate matrix from the seep and non-seep environments were analyzed, in order to evaluate whether the crinoid was intimately associated with the methane released from the seeps or not. If the crinoid utilized the cold seep methane for metabolism, it is expected that the fossil crinoid skeletons show a low $\delta^{13} \mathrm{C}$ signature.

The fossil samples of crinoid found from the Yezo Group were used for bulk analyses, because it was difficult to separate the skeletal parts from cement filling and surrounding them. Echinoderms including crinoids have high-Mg calcite endoskeletons that have a microscopically three-dimensional network structure called stereom (Smith 1980). When echinoderms are alive, the pore space in stereom is filled with soft tissue (stroma) and accounts for approximately half the volume of the skeleton (Savarese et al. 1997). After death, the space is later filled with cement or matrix during diagenesis. In this study, the samples, a mixture of crinoid skeletal part and the matrix or cement, were milled with a micro-milling drill to fine powder for isotope analysis. Therefore, the results of the stable isotopes analysis of "crinoids" were based on the mixture of crinoid skeletons and cement/matrix. For comparison, the following three sets of samples were analyzed: seep carbonate matrix, two isocrinid crinoid specimens came from Tappu, Hokkaido, which came from presumably Coniacian non-seep facies, and carbonate nodules containing these crinoid fossils from Tappu.

Approximately $100 \mu \mathrm{g}$ of fine powder of each sample was used for isotope analysis. Stable isotope ratio $\left(\delta^{13} \mathrm{C}\right.$ and $\left.\delta^{18} \mathrm{O}\right)$ was measured using an isotope ratio mass spectrometer (Delta V Plus, Thermo Fisher Scientific Inc., USA) connected to an automated carbonate reaction device (GasBench II, Thermo Fisher Scientific., USA) installed at Atmosphere and Ocean Research Institute, the University of Tokyo. The powder of each sample was introduced into a glass vial, flushed with pure helium and reacted with $100 \%$ phosphoric acid at $72^{\circ} \mathrm{C}$, and liberated $\mathrm{CO}_{2}$ was transported with the helium gas flow to the mass spectrometer. All isotopic data were calculated in parts permil (\%) relative to the VPDB (Vienna Pee Dee Belemnite) reference via the NBS-19 standard. Repeated analysis of NBS-19 yielded an external reproducibility of $\delta^{13} \mathrm{C}$ and $\delta^{18} \mathrm{O}$ measurements of better than $0.1 \% 0(1 \sigma)$.

\section{RESULTS}

\section{Microscopic observation and morphology of the crinoids}

The fossil crinoid obtained from the seep carbonates belongs to the suborder Isocrinina, because of its pentagonal to pentalobate outline of columnals with axial canal, and pentaradial arrangement of ligamentary fields on the colmunal surface (Fig. 2, A). The morphologies, for example, the size and the shape of columnals, are similar to those of the Isocrinina crinoid from non-seep locality in Tappu, and thus the species from both localities would be classified into close relatives. However, at present these crinoids are difficult to assign to a particular genus because detailed articulation pattern, or information about arm branching or brachial articulations are unknown.

Thin sections of the fossil crinoids from seep carbonate revealed existence of a mesh-like structure (stereom) in their skeleton parts (Fig. 3). The stereom structure suggests that the crinoid fossil is in a good state of preservation and it is expected to keep original isotope status in its skeleton (for further discussion see Kato et al. 2017). Thus, it is considered that the fossil crinoids used in this study were not suffered severe diagenesis, and are expected to keep initial stable isotope ratios. 

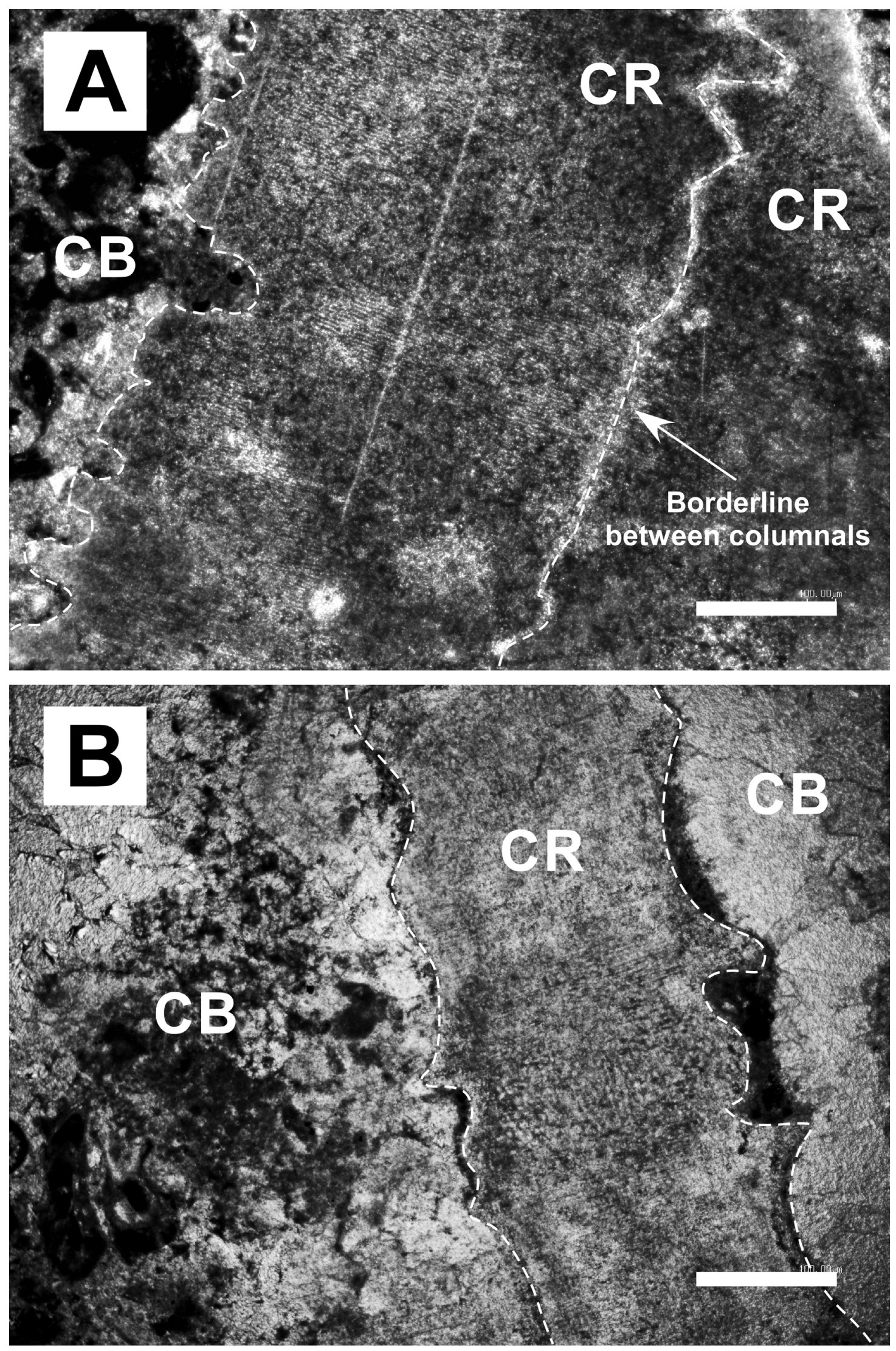

FIGURE 3. The thin sections of the fossil crinoid under the observation of a polarizing microscope. A and B, both using crosspolarized light; columnals of the crinoid from the cold seep carbonates. The mesh-like structure (stereom) can be observed in the columnals. CR is fossil crinoid colmnals and CB is seep carbonate. All scale bars $500 \mu \mathrm{m}$. 
TABLE 1. Carbon and oxygen isotopic values from the crinoid fossils and their matrix. These isotopic values were calculated in parts permil (\%) relative to the VPDB (Vienna Pee Dee Belemnite).

\begin{tabular}{|c|c|c|c|}
\hline & & $\delta^{13} \mathrm{C}(\%)$ & $\delta^{18} \mathrm{O}(\%)$ \\
\hline \multirow[t]{25}{*}{ Cold seep carbonate } & Crinoids & -31.7 & -1.4 \\
\hline & & -36.4 & -3.9 \\
\hline & & -32.9 & -2.6 \\
\hline & & -34.6 & -3.4 \\
\hline & & -26.6 & -6.7 \\
\hline & & -35.6 & -5.9 \\
\hline & & -22.4 & -8.5 \\
\hline & & -33.7 & -1.8 \\
\hline & & -36.4 & -1.6 \\
\hline & & -35.8 & -2.3 \\
\hline & Matrix & -27.6 & -2.4 \\
\hline & & -27.5 & -1.5 \\
\hline & & -21.8 & -3.9 \\
\hline & & -27.7 & -4.7 \\
\hline & & -27.6 & -4.8 \\
\hline & & -29.4 & -7.6 \\
\hline & & -35.6 & -6.6 \\
\hline & & -30.8 & -2.8 \\
\hline & & -28 & -4.3 \\
\hline & & -29.2 & -7.6 \\
\hline & & -30.9 & -7.6 \\
\hline & & -30.6 & -9.7 \\
\hline & & -16.2 & -10.6 \\
\hline & & -22.4 & -9.7 \\
\hline & & -15.3 & -10.1 \\
\hline \multirow[t]{10}{*}{ Non-seep facies } & Crinoid & -2.8 & -4.9 \\
\hline & & -2.3 & -4.7 \\
\hline & & -1.9 & -5.1 \\
\hline & & -2.9 & -5.3 \\
\hline & & -2.5 & -5.1 \\
\hline & Matrix & -5.4 & -6 \\
\hline & & -7.3 & -7.3 \\
\hline & & -5.9 & -6.7 \\
\hline & & -11.3 & -5.2 \\
\hline & & -13.3 & -6.9 \\
\hline
\end{tabular}

\section{Stable isotope ratios}

The $\delta^{13} \mathrm{C}$ and $\delta^{18} \mathrm{O}$ isotope values are presented in Table 1 and Figure 4. The $\delta^{13} \mathrm{C}$ values of the seep carbonates including matrix of fossils were very low, showing the average $-26.7 \% 0(\mathrm{n}=15, \mathrm{SD}=5.54)$ and those of crinoid columnals were much lower than the values of the matrix, showed the average $-32.6 \%$ o $(n=10, S D=$ 
4.63). The $\delta^{13} \mathrm{C}$ values of crinoids were generally lower than $-30 \%$ except two samples. The $\delta^{18} \mathrm{O}$ values of crinoids were not so different from the values of the matrix of the seep carbonates. The $\delta^{13} \mathrm{C}$ values of nonseep crinoid showed the average $-2.49 \%$ o $(n=5, S D=0.42)$, and the values were much higher than the values obtained from seep crinoids, and were comparable to the values from normal modern echinoderms (e.g. Weber \& Raup 1966). The $\delta^{13} \mathrm{C}$ values of carbonate nodule that contained non-seep crinoid showed the average $-8.65 \% 0(n=5, S D=3.50)$. The non-seep crinoid specimens had slightly higher $\delta^{13} \mathrm{C}$ values than the carbonate nodule.

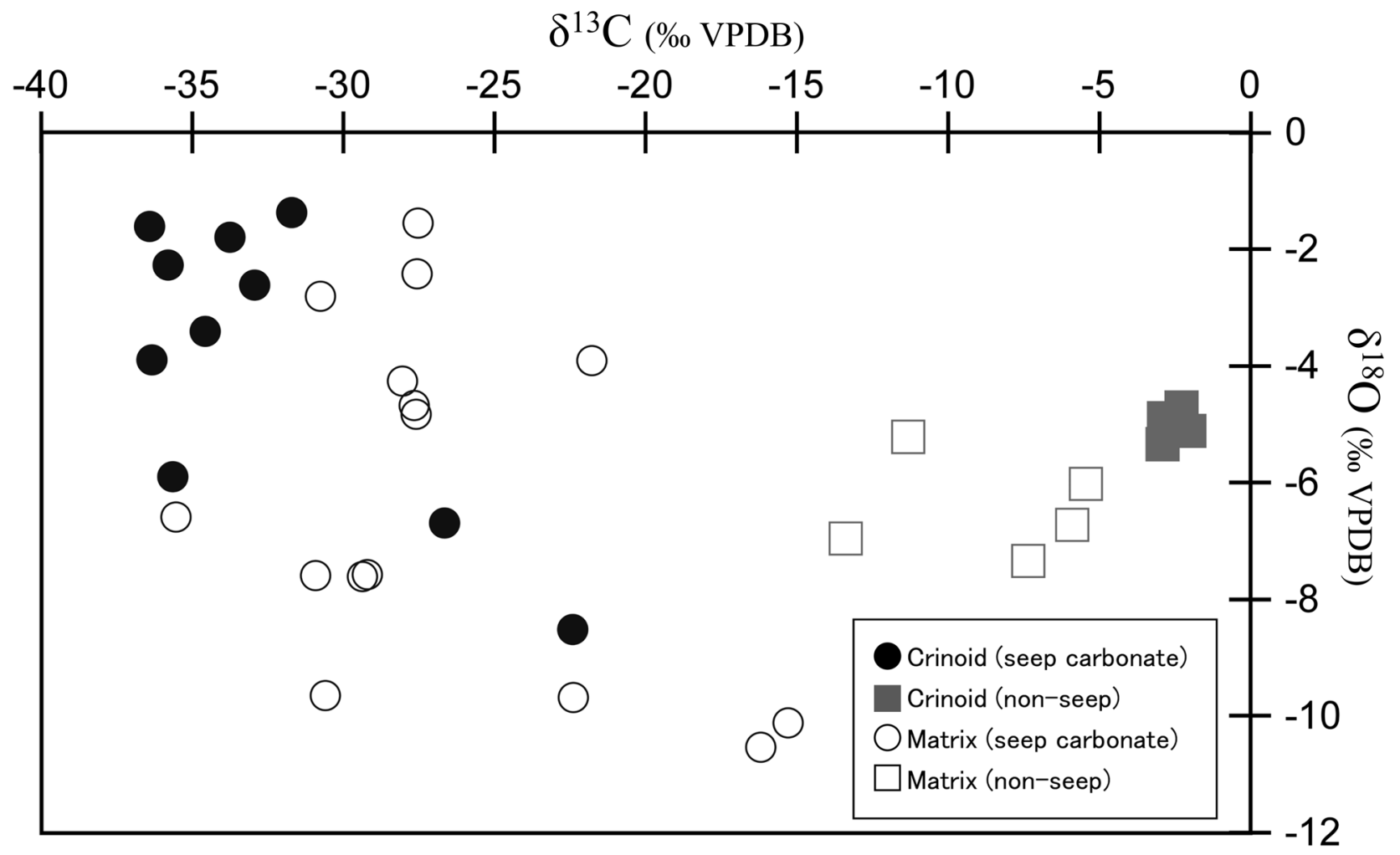

FIGURE 4. Cross-plot of carbon and oxygen isotopic composition of the crinoid fossils and their matrix. Circles show samples collected from the cold seep carbonate boulders, and squares show samples collected from non-seep facies.

\section{DISCUSSION}

In general, $\delta^{13} \mathrm{C}$ values of skeletal carbonate of living and fossil echinoderms range from -10 to $+4 \%$ (Weber \& Raup 1966; 1968; Weber 1968; Bill et al. 1995; Baumiller 2001; Gorzelak et al. 2012). The $\delta^{13} \mathrm{C}$ values of the seep crinoid from Hokkaido had extremely low $\delta^{13} \mathrm{C}$ values (ranging from -22.4 to $-36.4 \%$ with a mean $-32.6 \%$ ( $\mathrm{SD}=4.7)$ with a median of $-34.2 \%$ ). These $\delta^{13} \mathrm{C}$ values are considerably lower than those of known modern and fossil echinoderms, including crinoids from non-seep environment. As mentioned previously, for the analysis of the seep crinoids, mixtures of crinoid skeletons and cement/matrix which filled stereom pores were used. If the $\delta^{13} \mathrm{C}$ values of the cement/matrix was almost the same as that of seep carbonates (the average $-26.7 \%$ ), the precise $\delta^{13} \mathrm{C}$ values of the crinoid skeleton without cement/matrix would be lower than that of the mixtures.

The carbon sources of echinoderm skeletons are unclear, however it is thought to be derived either from dissolved inorganic carbon $\left(\mathrm{CO}_{2}\right)$ in ambient seawater or perhaps from their foods. The ambient water cannot show remarkably low isotope ratios even if taken near cold seep environments, considering the results of stable carbon analyses of seep bivalves and ammonoids which had secreted their shells in isotopic equilibrium with seawater, around $-5 \%$ (e.g. Landman et al. 2012). Therefore, the low $\delta^{13} \mathrm{C}$ values of the seep crinoid from Hokkaido are thought to reflect those of their foods rather than the surrounding water. Thus, the seep 
crinoid from Hokkaido should have utilized organic matter produced through chemosynthesis in cold seep environments for their metabolism including secreting their skeleton. It is the second example of fossil crinoids that used chemosynthetic products, next to Lakotacrinus brezinai (Hunter et al. 2016; Kato et al. 2017).

Lakotacrinus brezinai, fossil crinoid from seep deposits in the Pierre Shale Formation, USA, shows very peculiar morphologies that are not seen in other crinoids, for example, many longitudinal tubulis, unbranching five arms and short stalk with no attachment structure (Hunter et al. 2016). However, as long as the examination of the columnals, the morphology of the seep crinoid from Hokkaido is essentially similar to fossil crinoids occurred from non-seep deposits of the almost same age and locality. If the seep crinoid is identical to the crinoids from non-seep deposits, the seep crinoid is not a member of "seep-restricted fauna". The seep crinoid samples from Hokkaido are found from only one locality, and they may be allochthonous, because it was found in a fragmental condition. Therefore, it is thought that the seep crinoid from Hokkaido had lived near the cold seep environment and their diets had been mainly organic matter which was produced in cold seep environments and had low $\delta^{13} \mathrm{C}$ values. If so, the seep crinoid from Hokkaido is concluded as dependent on energy from cold seep environments as "background fauna". It is also thought that the cold seep environments have played a role as a nutrient source for not only chemosynthetic community members, but also organisms living in the surrounding environments.

\section{CONCLUSIONS}

1. Columnals of a fossil crinoid identified as belonging to the suborder Isocrinina were found from a seep carbonate in the Yezo Group, Hokakido, and this occurrence is the second example of fossil crinoid from cold seep deposits. The crinoid species would be identical to or at least close relatives of the isocrinid species that lived in non-seep environments in adjacent area because of their morphological similarity.

2. $\delta^{13} \mathrm{C}$ values of the fossil crinoid skeletons from Hokkaido showed very low, about $-30 \%$ VPDB, and these data were lower than those of the matrix carbonates of these fossils. This result demonstrated that the crinoids associated with cold seep methane in metabolically.

3. According to these results, it is concluded that the fossil crinoids lived not in but near a cold seep environment and utilized organic matter with low $\delta^{13} \mathrm{C}$ values, which were produced through chemosynthesis in cold seep environment.

\section{ACKNOWLEDGEMENTS}

I am deeply grateful to Professor Tatsuo Oji (Nagoya University Museum; NUM) who provided me some samples of the fossil crinoids and offered continuing support. I thank Professor Yuji Sano (The Atmosphere and Ocean Research Institute at the University of Tokyo; AORI) for permission to use an isotope ratio mass spectrometer Delta Plus, Thermo Fisher Scientific and for many valuable advices. Dr. Kotaro Shirai and Noriko Izumoto (both AORI) gave me constructive comments and technical help about stable isotope analysis. Isotope measurements were conducted at Atmosphere and Ocean Research Institute, the University of Tokyo. Thanks are extended to Dr. Robert G. Jenkins (Kanazawa University) and Dr. Yoshinori Hikida (Nakagawa Museum of natural History, Nakagawa Town, Hokkaido) for their useful comments and enormous help in the field in Hokkaido, and to Dr. Kyo Tanoue (Fukuoka University) for collecting and providing me some samplesof the fossil crinoids. I thank Dr. Mariusz A. Salamon as a reviewer and for his important comments. This work was supported by Japan Society for the Promotion of Science for Young Scientists (No. 26010022 for M.K.) and Grant-in-Aide for the scientific Research Kakenhi (No. 26287131 for T.O.).

\section{REFERENCES}

Baumiller, T.K. (2001) Light stable isotope geochemistry of the crinoid skeleton and its use in biology and paleobiology. In: Barker, M. (Ed.), Echinoderms 2000. Balkema, Lisse, pp. 107-112. 
Bill, M., Peter, O.B. \& Johannes, C.H. (1995) Carbon-isotope stratigraphy of beds member (Oxfordian, Swiss-Jura) using echinoids and crinoids. Eclogae Geologicae Helvetiae, 88, 135-155.

Campbell, K.A. (2006) Hydrocarbon seep and hydrothermal vent palaeoenvironments and palaeontology: past developments and future research directions. Palaeogeography, Palaeoclimatology, Palaeoecology, 232, 362-407. https://doi.org/10.1016/j.palaeo.2005.06.018

Campbell, K.A., Farmer, J.D. \& Des Marais, D. (2002) Ancient hydrocarbon seeps from the Mesozoic convergent margin of California: carbonate geochemistry, fluids and paleoenvironments. Geoguids, 2, 63-94. https://doi.org/10.1046/j.1468-8123.2002.00022.x

Gorzelak, P., Stolarski, J., Małkowski, K. \& Meibom, A. (2012) Stable Carbon and Oxygen Isotope Compositions of Extant Crinoidal Echinoderm Skeletons. Chemical Geology, 291, 132-140. https://doi.org/10.1016/j.chemgeo.2011.10.014

Hikida, Y., Suzuki, S., Togo, Y. \& Ijiri, A. (2003) An exceptionally well-preserved seep community from the Cretaceous Yezo forearc basin in Hokkaido, northern Japan. Palaeontological Research, 7, 329-432. https://doi.org/10.2517/prpsj.7.329

Jenkins, R.G., Kaim, A., Hikida, Y. \& Tanabe, K. (2007) Methane-flux-dependent lateral faunal changes in a Late Cretaceous chemosymbiotic assemblage from the Nakagawa area of Hokkaido, Japan. Geobiology, 5 (2), 127-139. https://doi.org/10.1111/j.1472-4669.2007.00106.x

Hunter, A.W., Larson, N.L., Landman, N.H. \& Oji, T. (2016) Lakotacrinus brezinai n. gen. n. sp., a new stalked crinoid from cold methane seeps in the Upper Cretaceous (Campanian) Pierre Shale, South Dakota, United States. Journal of Paleontology, 90, 506-524. https://doi.org/10.1017/jpa.2016.21

Kaim, A., Jenkins, R.G. \& Warén, A. (2008) Provannid and provannid-like gastropods from Late Cretaceous cold seeps of Hokkaido (Japan) and the fossil record of the Provannidae (Gastropoda: Abyssochrysoidea). Linnean Society Zoological Journal, 154, 421-436. https://doi.org/10.1111/j.1096-3642.2008.00431.x

Kato, M., Oji, T. \& Shirai, K. (2017) Paleoecology of Echinoderms in cold seep environments revealed by isotope analysis in the Late Cretaceous Western Interior Seaway. PALAIOS, 32, 218-230. https://doi.org/10.2110/palo.2016.079

Landman, N.H., Cochran, J.K., Larson, N.L., Brezina, J., Garb, M. P. \& Harries, P.J. (2012) Methane seeps as ammonite habitats in the U.S. Western Interior Seaway revealed by isotopic analyses of well-preserved shell material. Geology, 40, 507-510. https://doi.org/10.1130/G32782.1

Levin, L.A. (2005) Ecology of cold seep sediments: interactions of fauna with flow, chemistry and microbes. Oceanography and Marine Biology: An annual Review, 43, 1-46. https://doi.org/10.1201/9781420037449.ch1

Paull, C.K., Hecker, B., Commeau, R., Freeman-Lynde, R.P., Neumann, C., Corso, W.P., Golubic, S., Hook, J.E., Sikes, E. \& Curray, J. (1984) Biological Communities at the Florida Escarpment Resemble Hydrothermal Vent Taxa. Science, 226, 965-967. https://doi.org/10.1126/science.226.4677.965

Peckmann, J. \& Thiel, V. (2004) Carbon cycling at ancient methane-seeps. Chemical Geology, 205, 443-467. https://doi.org/10.1016/j.chemgeo.2003.12.025

Savarese, M., Dodd, J.R. \& Lane, N.G. (1997) Taphonomic and sedimentologic implications of crinoid intraskeletal porosity. Lethaia, 29, 141-156. https://doi.org/10.1111/j.1502-3931.1996.tb01870.x

Sibuet, M. \& Olu, K. (1998) Biogeography, biodiversity and fluid dependence of deep-sea cold-seep communities at active and passive margins. Deep-Sea Research II, 45, 517-567. https://doi.org/10.1016/S0967-0645(97)00074-X

Smith, A.B. (1980) Stereom microstructure of the echinoid test. Special Papers in Palaeontology, 25, 1-81.

Takahashi, A., Hirano, H. \& Sato, T. (2003) Stratigraphy and fossil assemblage of the Upper Cretaceous in the Teshionakagawa area, Hokkaido, northern Japan. Journal of the Geological Society of Japan, 109, 77-95. https://doi.org/10.5575/geosoc.109.77

Takashima, R., Kawabe, F., Nishi, H., Moriya, K., Wani, R. \& Ando, H. (2004) Geology and stratigraphy of forearc basin sediments in Hokkaido, Japan: Cretaceous environmental events on the north-west Pacific margin. Cretaceous Research, 25, 365-390.

https://doi.org/10.1016/j.cretres.2004.02.004 
Weber, J.N. (1968) Fractionation of the stable isotopes of carbon and oxygen in calcareous marine invertebrates-the asteroidea, Ophiuroidea and Crinoidea. Geochimica et Cosmochimica Acta, 32, 33-70. https://doi.org/10.1016/0016-7037(68)90087-2

Weber, J.N. \& Raup, D.M. (1966) Fraction of the stable isotopes of carbon and oxgen in marine calcareous organisms-the Echinoidea. Part 1. Variation of $\mathrm{C}^{13}$ and $\mathrm{O}^{18}$ content within individuals. Geochimica et Cosmochimica Acta, 30, 681-703. https://doi.org/10.1016/0016-7037(66)90097-4

Weber, J.N. \& Raup, D.M. (1968) Composition of C13/C12 and O18/O16 in the skeletal of recent and fossil echinoids. Journal of Paleontology, 42, 37-50. 